\title{
Effect of hypoxia on equine mesenchymal stem cells derived from bone marrow and adipose tissue
}

Beatriz Ranera ${ }^{1}$, Ana Rosa Remacha', Samuel Álvarez-Arguedas ${ }^{1}$, Antonio Romero², Francisco José Vázquez², Pilar Zaragoza', Inmaculada Martín-Burriel ${ }^{1}$ and Clementina Rodellar ${ }^{1,3^{*}}$

\begin{abstract}
Background: Mesenchymal stem cells (MSCs) derived from bone marrow (BM-MSCs) and adipose tissue (AT-MSCs) are being applied to equine cell therapy. The physiological environment in which MSCs reside is hypoxic and does not resemble the oxygen level typically used in in vitro culture $\left(20 \% \mathrm{O}_{2}\right)$. This work compares the growth kinetics, viability, cell cycle, phenotype and expression of pluripotency markers in both equine BM-MSCs and AT-MSCs at 5\% and $20 \% \mathrm{O}_{2}$.

Results: At the conclusion of culture, fewer BM-MSCs were obtained in hypoxia than in normoxia as a result of significantly reduced cell division. Hypoxic AT-MSCs proliferated less than normoxic AT-MSCs because of a significantly higher presence of non-viable cells during culture. Flow cytometry analysis revealed that the immunophenotype of both MSCs was maintained in both oxygen conditions. Gene expression analysis using RT-qPCR showed that statistically significant differences were only found for CD49d in BM-MSCs and CD44 in AT-MSCs. Similar gene expression patterns were observed at both 5\% and $20 \% \mathrm{O}_{2}$ for the remaining surface markers. Equine MSCs expressed the embryonic markers NANOG, OCT4 and SOX2 in both oxygen conditions. Additionally, hypoxic cells tended to display higher expression, which might indicate that hypoxia retains equine MSCs in an undifferentiated state.
\end{abstract}

Conclusions: Hypoxia attenuates the proliferative capacity of equine MSCs, but does not affect the phenotype and seems to keep them more undifferentiated than normoxic MSCs.

Keywords: Hypoxia, Horse, AT-MSC, BM-MSC, Characterisation

\section{Background}

In recent years, mesenchymal stem cells (MSCs) have become increasingly utilised in regenerative medicine and tissue engineering applications because of their properties for self-renewal, differentiation and immunoregulation [1].

To study these properties, MSCs must be isolated from their physiological niches and cultured ex vivo. The micro-environment that cells experience in laboratory culture is very different from their native settings; therefore, it is possible that the true in vivo properties of

\footnotetext{
* Correspondence: rodellar@unizar.es

'Laboratorio de Genética Bioquímica (LAGENBIO), Facultad de Veterinaria, Universidad de Zaragoza, 50013 Zaragoza, Spain

${ }^{3}$ Instituto Aragonés de Ciencias de la Salud (IACS), Zaragoza 50009, Spain Full list of author information is available at the end of the article
}

these cells might be modified by artificial culture. One environmental property that is commonly altered by the change of environment is the percentage of oxygen. Traditional incubators are supplied with atmospheric air that contains $20 \%$ oxygen (defined as "normoxia"), which is a not physiologically accurate for any kind of cell. Two common MSC sources are bone marrow and adipose tissue, in which the oxygen tension ranges from $1 \%-7 \%$ [2] and $2 \%-8 \%$ [3], respectively.

All nucleated cells are able to sense and respond to the availability of $\mathrm{O}_{2}$ [4]. Rat MSCs modify the expression of molecules involved in cell proliferation and survival when they are exposed to low oxygen tensions that approximate physiological conditions [5]. Hypoxia inducible factor $1 \alpha$ (HIF-1 $\alpha)$ regulates the expression of many

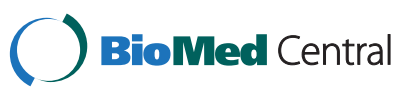


cell cycle molecules, including p21, anti-apoptotic factors, such as Bcl-2 [6], and pro-apoptotic proteins, such as p53 [7]. Consequently, rat MSCs exhibit different proliferation rates when cell expansion under hypoxia and normoxia are compared; however, some controversy exists regarding whether low oxygen tension enhances [8] or suppresses proliferation [9]. Additionally, oxygen plays an important role in the differentiation [10] and maintenance of stemness in MSCs [11].

Due to the inability of tendons and articulations to heal properly, MSC-based therapies have been utilised in horses to treat orthopaedic disorders resulting from sporting endeavours [12,13]. Oxygen levels in cartilage are among the lowest throughout the body [14], and hypoxia appears to be essential for tendon repair [15]. In addition, hypoxic preconditioning improves the therapeutic potential of human MSCs [16]. Taken together, these facts suggest that horse MSCs cultured in hypoxia might constitute a more relevant model for the treatment of injuries in low-oxygen tissues than those currently utilised, which are usually cultured in $20 \% \mathrm{O}_{2}$.

To improve the methodology for equine stem cell therapy, it is necessary to examine the characteristics and to compare the behaviour of MSCs in normoxic and hypoxic conditions. Specifically, this study contrasts the proliferation kinetics, viability, cell cycle progression, phenotype and stemness of MSCs derived from bone marrow (BM-MSCs) and adipose tissue (AT-MSCs) cultured in $5 \%$ and $20 \% \mathrm{O}_{2}$.

\section{Results}

\section{Proliferation kinetics}

The growth kinetics of BM- and AT-MSCs expanded in normoxia and hypoxia were monitored for 7 days. Normoxic MSCs derived from both sources displayed higher number of cells than hypoxic MSCs at the end of the culture.
BM-MSCs exposed to both oxygen conditions showed similar lag phase (Figure 1A); however, the log phase lasted less in hypoxic BM-MSCs, until day 5, when they reached a growth plateau state, while normoxic BMMSCs continued growing slowing down their proliferation the last day of the culture period.

Similarly to BM-MSCs, AT-MSCs at 5\% and 20\% $\mathrm{O}_{2}$ showed similar lag phase and the log phase ended before in hypoxic than in normoxic AT-MSCs, which went on the log phase until the end of the culture period (Figure 1B). Significantly higher number of AT-MSCs in normoxic cultures was detected on days 5 and 7 .

\section{Cell cycle}

To examine the cell cycle progression under both oxygen conditions, cellular DNA content was quantified in the cultures used in the proliferation study for 7 days. Figure 2 shows the proportions of cells in each cell cycle phase observed in BM- and AT-MSCs expanded in normoxia and hypoxia.

Cell cycle data obtained for BM-MSC cultures showed that normoxic cells were more active than hypoxic cells from day 2 (Table 1A). Significantly higher percentage of normoxic BM-MSCs was observed in $\mathrm{S}$ phase on days 2 and 4 , and in $G_{2} / M$ phases on day 2. Supporting this finding, significantly higher proportion of hypoxic BMMSCs in $G_{0} / G_{1}$ phases was found on days 2,3 and 4 . However, hypoxic and normoxic AT-MSCs did not display any statistically significant difference over the course of the culture period (Table 1B).

Comparing normoxic cultures of BM-MSCs and ATMSCs, BM-MSCs displayed a significantly higher percentage of cells in $G_{0} / G_{1}$ and reduced frequency of cells in S phase compared with AT-MSCs on days 2 and 3. The proportions of cells in each phase of the cell cycle were comparable throughout the remaining time course (Table 1C).
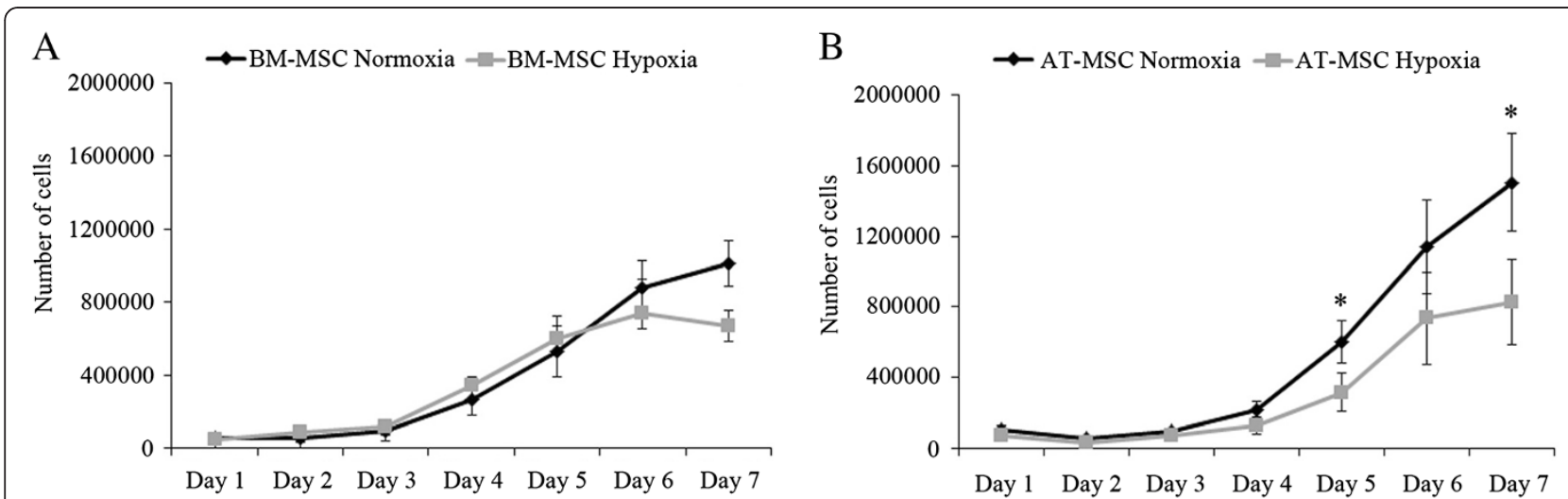

Figure 1 Growth kinetic curves of equine MSCs at different oxygen concentrations. Growth kinetics of BM-MSCs ( $\mathrm{n}=6)(\mathbf{A})$ and AT-MSCs $(n=6)(\mathbf{B})$. The $Y$ axis represents the number of cells, and the $X$ axis represents the number of days in culture. Data are represented as the means \pm standard deviation. Black lines correspond to MSCs exposed to $20 \% \mathrm{O}_{2}$, and grey lines to MSCs exposed to $5 \%$ O ${ }_{2}$. $P$ < 0.05 ). 

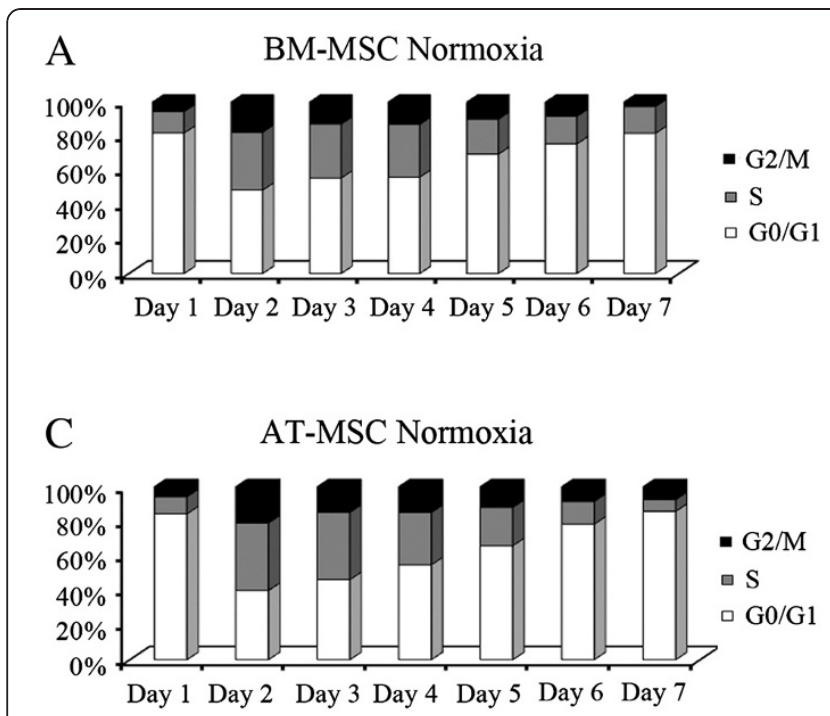
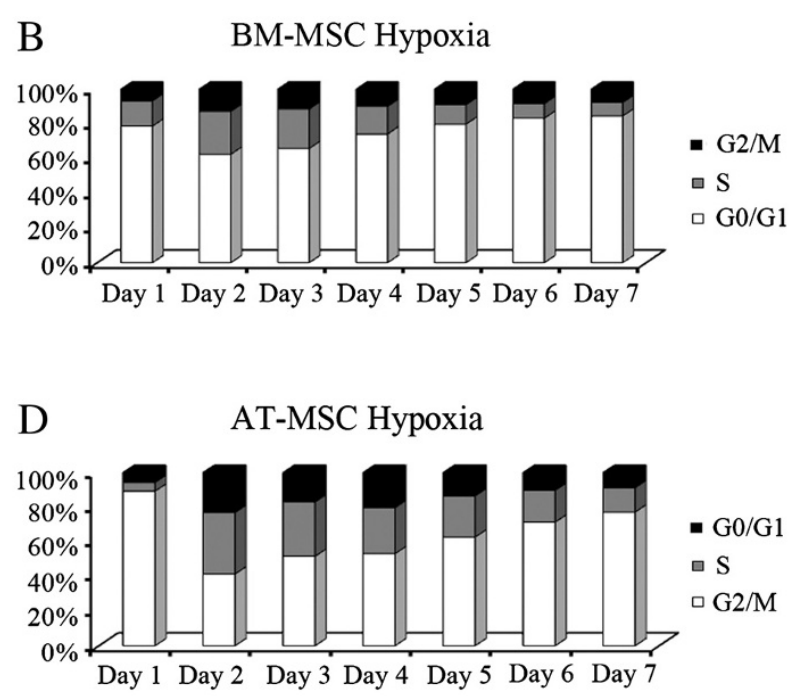

Figure 2 Cell cycle of equine BM-MSCs and AT-MSCs in normoxic and hypoxic conditions. Changes of the proportion at cell cycle phases of normoxic BM-MSCs (A), hypoxic BM-MSCs (B), normoxic AT-MSCs (C) and hypoxic AT-MSCs (D) for 7 days. Y axis represent the percentage of total cells and the $X$ axis represents the culture days. Black sections represent cells in $\mathrm{G}_{2} / \mathrm{M}$ phases, grey sections represent cells in $\mathrm{S}$ phase and white sections represent cells in $G_{0} / G_{1}$ phases.

Differences in cell cycle progression in hypoxic MSCs derived from both sources were more marked than in normoxia (Table 1D). On the first day of culture, there were significantly higher percentages of AT-MSCs in $\mathrm{G}_{0} / \mathrm{G}_{1}$ phase and of BM-MSCs in $\mathrm{S}$ phase. However, in the following days, until day 5 , this behaviour was inverted: significantly more BM-MSC were in $G_{0} / G_{1}$, whereas AT-MSCs were more active in cell division and more abundant in $\mathrm{S}$ phase on days 2,4 and 5 and in $G_{2} / M$ phase on days 2 and 3.

\section{Cell viability}

Possible changes in apoptosis and viability were monitored in the cells used in the proliferation study during 7 days using Annexin V (AnV) and propidium iodide (PI). Figure 3 shows the proportions of viable, apoptotic and non-viable cells in the different cultures during the culture period.

BM-MSCs expanded in both oxygen atmospheres showed similar proportions of apoptotic $\left(\mathrm{AnV}^{+} \mathrm{PI}^{-}\right)$and non-viable cells $\left(\mathrm{PI}^{+}\right)$during the 7 days of culture (Table 2A). However, on culture days 1, 2, 3 and 5, a significantly higher proportion of viable cells was observed in normoxic AT-MSCs than in hypoxic AT-MSCs (Table 2B). These differences were associated with a significantly higher frequency of $\mathrm{PI}^{+}$cells in hypoxic conditions on days 3, 4, 5 and 7, while the proportion of $\mathrm{AnV}^{+} \mathrm{PI}^{-}$cells was similar for both conditions and never higher than $10 \%$ of the total population.

Comparing the viability of normoxic BM-MSC and AT-MSC culture (Table 2C), the proportions of viable BM-MSCs were significantly higher than in AT-MSCs until day 3. Since then this trend reversed, being the proportion of viable cells significantly higher in AT-MSCs than in BM-MSCs on days 4 and 5. The differences in viability between both cell types observed at early stages of culture resulted from a significantly higher proportion of non-viable AT-MSCs on days 1 and 2; as the time of culture went by, the percentage of $\mathrm{PI}^{+}$AT-MSCs became similar and the proportion of apoptotic BM-MSCs increased, being significantly higher on days 2, 4, 5 and 6 .

The behaviour displayed by BM-MSCs and AT-MSCs in hypoxia was similar to their normoxic equivalents until day 4 (i.e., significantly higher percentages of $\mathrm{PI}^{+}$ and lower percentages of $\mathrm{AnV}^{-} \mathrm{PI}^{-}$cells were detected in AT-MSC cultures). However, unlike normoxic MSCs, these results were maintained until the end of the culture period. In addition, the proportion of $\mathrm{AnV}^{+} \mathrm{PI}^{-}$was similar for both cell types, which contrasts with the results of comparisons between normoxic MSCs (Table 2D).

\section{Immunophenotype and gene expression patterns of} surface markers

The immunophenotype for the surface markers CD29 and CD90 was analysed using flow cytometry, which revealed similar expression patterns for the MSCs independently of source or oxygen atmosphere (Table 3). In all cases, the percentage of positive cells was greater than $93 \%$.

In addition to flow cytometry, real time quantitative PCR (RT-qPCR) was performed to assess the expression of $C D 29$ and $C D 90$, as well as 8 additional surface antigens (Figure 4). Few significant differences in gene expression were found between cells from the same origin 
Table 1 Analysis of cell cycle in BM-MSCs $(n=6)$ and AT-MSCs $(n=6)$ cultured under hypoxic or normoxic conditions

\begin{tabular}{|c|c|c|c|c|c|c|c|c|c|}
\hline & \multicolumn{2}{|c|}{ A } & \multicolumn{2}{|c|}{ B } & \multicolumn{2}{|c|}{ C } & \multicolumn{2}{|c|}{$D$} \\
\hline & & \multicolumn{2}{|c|}{ BM-MSC } & \multicolumn{2}{|c|}{ AT-MSC } & \multicolumn{2}{|c|}{ Normoxia } & \multicolumn{2}{|c|}{ Hypoxia } \\
\hline & & Normoxia & Hypoxia & Normoxia & Hypoxia & BM-MSC & AT-MSC & BM-MSC & AT-MSC \\
\hline \multirow[t]{3}{*}{ Day 1} & $\mathrm{G}_{0}-\mathrm{G}_{1}$ & $81.88 \pm 15.37$ & $78.64 \pm 10.64$ & $84.33 \pm 9.48$ & $89.04 \pm 5.98$ & $81.88 \pm 15.37$ & $84.33 \pm 9.48$ & $78.64 \pm 10.64^{a}$ & $89.04 \pm 5.98^{b}$ \\
\hline & S & $12.51 \pm 10.53$ & $14.51 \pm 7.39$ & $9.86 \pm 7.17$ & $4.99 \pm 3.12$ & $12.51 \pm 10.53$ & $9.86 \pm 7.17$ & $14.51 \pm 7.39^{a}$ & $4.99 \pm 3.12^{b}$ \\
\hline & $\mathrm{G}_{2}-\mathrm{M}$ & $5.61 \pm 5.30$ & $6.85 \pm 4.70$ & $5.80 \pm 2.42$ & $5.74 \pm 3.10$ & $5.61 \pm 5.30$ & $5.80 \pm 2.42$ & $6.85 \pm 4.70$ & $5.74 \pm 3.10$ \\
\hline \multirow[t]{3}{*}{ Day 2} & $\mathrm{G}_{0}-\mathrm{G}_{1}$ & $49.32 \pm 4.46^{\mathrm{a}}$ & $62.64 \pm 5.52^{b}$ & $39.86 \pm 3.26$ & $41.33 \pm 6.23$ & $49.32 \pm 4.46^{a}$ & $39.86 \pm 3.26^{b}$ & $62.64 \pm 5.5^{\mathrm{a}}$ & $41.33 \pm 6.23^{b}$ \\
\hline & $S$ & $33.93 \pm 6.05^{\mathrm{a}}$ & $24.51 \pm 5.29^{b}$ & $39.07 \pm 1.50$ & $35.54 \pm 7.66$ & $33.93 \pm 6.05^{a}$ & $39.07 \pm 1.50^{b}$ & $24.51 \pm 5.29^{a}$ & $35.54 \pm 7.66^{b}$ \\
\hline & $\mathrm{G}_{2}-\mathrm{M}$ & $17.89 \pm 6.99^{\mathrm{a}}$ & $12.85 \pm 3.67^{b}$ & $21.07 \pm 3.52$ & $23.13 \pm 2,20$ & $17.89 \pm 6.99$ & $21.07 \pm 3.52$ & $12.85 \pm 3.67^{\mathrm{a}}$ & $23.13 \pm 2,20^{b}$ \\
\hline \multirow[t]{3}{*}{ Day 3} & $\mathrm{G}_{0}-\mathrm{G}_{1}$ & $56.00 \pm 5.85^{a}$ & $65.96 \pm 5.83^{b}$ & $45.37 \pm 3.85$ & $51.57 \pm 5.86$ & $56.00 \pm 5.85^{a}$ & $45.37 \pm 3.85^{b}$ & $65.96 \pm 5.83^{a}$ & $51.57 \pm 5.86^{b}$ \\
\hline & $S$ & $31.36 \pm 8.24$ & $22.53 \pm 5.18$ & $38.36 \pm 4.49$ & $31.42 \pm 9.07$ & $31.36 \pm 8.24^{a}$ & $38.36 \pm 4.49^{b}$ & $22.53 \pm 5.18$ & $31.42 \pm 9.07$ \\
\hline & $\mathrm{G}_{2}-\mathrm{M}$ & $12.94 \pm 4.46$ & $11.50 \pm 3.31$ & $14.60 \pm 1.04$ & $17.01 \pm 6.58$ & $12.94 \pm 4.46$ & $14.60 \pm 1.04$ & $11.50 \pm 3.31^{\mathrm{a}}$ & $17.01 \pm 6.58^{b}$ \\
\hline \multirow[t]{3}{*}{ Day 4} & $\mathrm{G}_{0}-\mathrm{G}_{1}$ & $56.30 \pm 5.65^{a}$ & $74.13 \pm 7.11^{b}$ & $54.67 \pm 2.64$ & $52.74 \pm 6.51$ & $56.30 \pm 5.65$ & $54.67 \pm 2.64$ & $74.13 \pm 7.11^{a}$ & $52.74 \pm 6.51^{b}$ \\
\hline & S & $30.59 \pm 10.05^{a}$ & $15.90 \pm 6.12^{b}$ & $30.24 \pm 1.30$ & $26.40 \pm 3.42$ & $30.59 \pm 10.05$ & $30.24 \pm 1.30$ & $15.90 \pm 6.12^{a}$ & $26.40 \pm 3.42^{b}$ \\
\hline & $\mathrm{G}_{2}-\mathrm{M}$ & $13.00 \pm 5.00$ & $9.97 \pm 4.26$ & $14.91 \pm 2.34$ & $20.19 \pm 8.15$ & $13.00 \pm 5.00$ & $14.91 \pm 2.34$ & $9.97 \pm 4.26$ & $20.19 \pm 8.15$ \\
\hline \multirow[t]{3}{*}{ Day 5} & $\mathrm{G}_{0}-\mathrm{G}_{1}$ & $69.77 \pm 11.77$ & $79.77 \pm 7.22$ & $65.83 \pm 5.76$ & $62.63 \pm 9.25$ & $69.77 \pm 11.77$ & $65.83 \pm 5.76$ & $79.77 \pm 7.22^{\mathrm{a}}$ & $62.63 \pm 9.25^{b}$ \\
\hline & S & $20.16 \pm 13.11$ & $11.18 \pm 4.44$ & $22.18 \pm 3.15$ & $23.85 \pm 5.48$ & $20.16 \pm 13.11$ & $22.18 \pm 3.15$ & $11.18 \pm 4.44^{a}$ & $23.85 \pm 5.48^{b}$ \\
\hline & $\mathrm{G}_{2}-\mathrm{M}$ & $10.07 \pm 2.33$ & $9.06 \pm 5.04$ & $11.99 \pm 2.75$ & $13.55 \pm 4.23$ & $10.07 \pm 2.33$ & $11.99 \pm 2.75$ & $9.06 \pm 5.04$ & $13.55 \pm 4.23$ \\
\hline \multirow[t]{3}{*}{ Day 6} & $\mathrm{G}_{0}-\mathrm{G}_{1}$ & $75.51 \pm 15.79$ & $83.07 \pm 6.31$ & $78.36 \pm 1.89$ & $71.49 \pm 11.70$ & $75.51 \pm 15.79$ & $78.36 \pm 1.89$ & $83.07 \pm 6.31$ & $71.49 \pm 11.70$ \\
\hline & $S$ & $16.08 \pm 15.59$ & $8.42 \pm 3.02$ & $13.16 \pm 1.80$ & $18.43 \pm 9.18$ & $16.08 \pm 15.59$ & $13.16 \pm 1.80$ & $8.42 \pm 3.02$ & $18.43 \pm 9.18$ \\
\hline & $\mathrm{G}_{2}-\mathrm{M}$ & $8.36 \pm 1.67$ & $8.35 \pm 5.52$ & $8.49 \pm 1.01$ & $10.35 \pm 2.53$ & $8.36 \pm 1.67$ & $8.49 \pm 1.01$ & $8.35 \pm 5.52$ & $10.35 \pm 2.53$ \\
\hline \multirow[t]{3}{*}{ Day 7} & $\mathrm{G}_{0}-\mathrm{G}_{1}$ & $81.71 \pm 6.83$ & $84.50 \pm 8.33$ & $85.78 \pm 1.56$ & $77.16 \pm 12.67$ & $81.71 \pm 6.83$ & $85.78 \pm 1.56$ & $84.50 \pm 8.33$ & $77.16 \pm 12.67$ \\
\hline & S & $15.65 \pm 16.21$ & $7.78 \pm 4.03$ & $6.73 \pm 1.32$ & $14.06 \pm 9.66$ & $15.65 \pm 16.21$ & $6.73 \pm 1.32$ & $7.78 \pm 4.03$ & $14.06 \pm 9.66$ \\
\hline & $\mathrm{G}_{2}-\mathrm{M}$ & $2.64 \pm 2.01$ & $7.77 \pm 4.92$ & $7.50 \pm 1.26$ & $8.78 \pm 3.20$ & $2.64 \pm 2.01$ & $7.50 \pm 1.26$ & $7.77 \pm 4.92$ & $8.78 \pm 3.20$ \\
\hline
\end{tabular}

The $G_{0} / G_{1}, S$ and $G_{2} / M$ cell cycle phases were analysed for 7 days. Cell cycle data are represented as the mean \pm standard deviation. The "a" and "b" superscripted bold data are significantly different. (A) Compares normoxic and hypoxic conditions of BM-MSCs; (B) compares normoxic and hypoxic conditions of AT-MSCs; (C) compares BM-MSCs and AT-MSCs in normoxic conditions; and (D) compares BM-MSCs and AT-MSCs in hypoxic conditions.

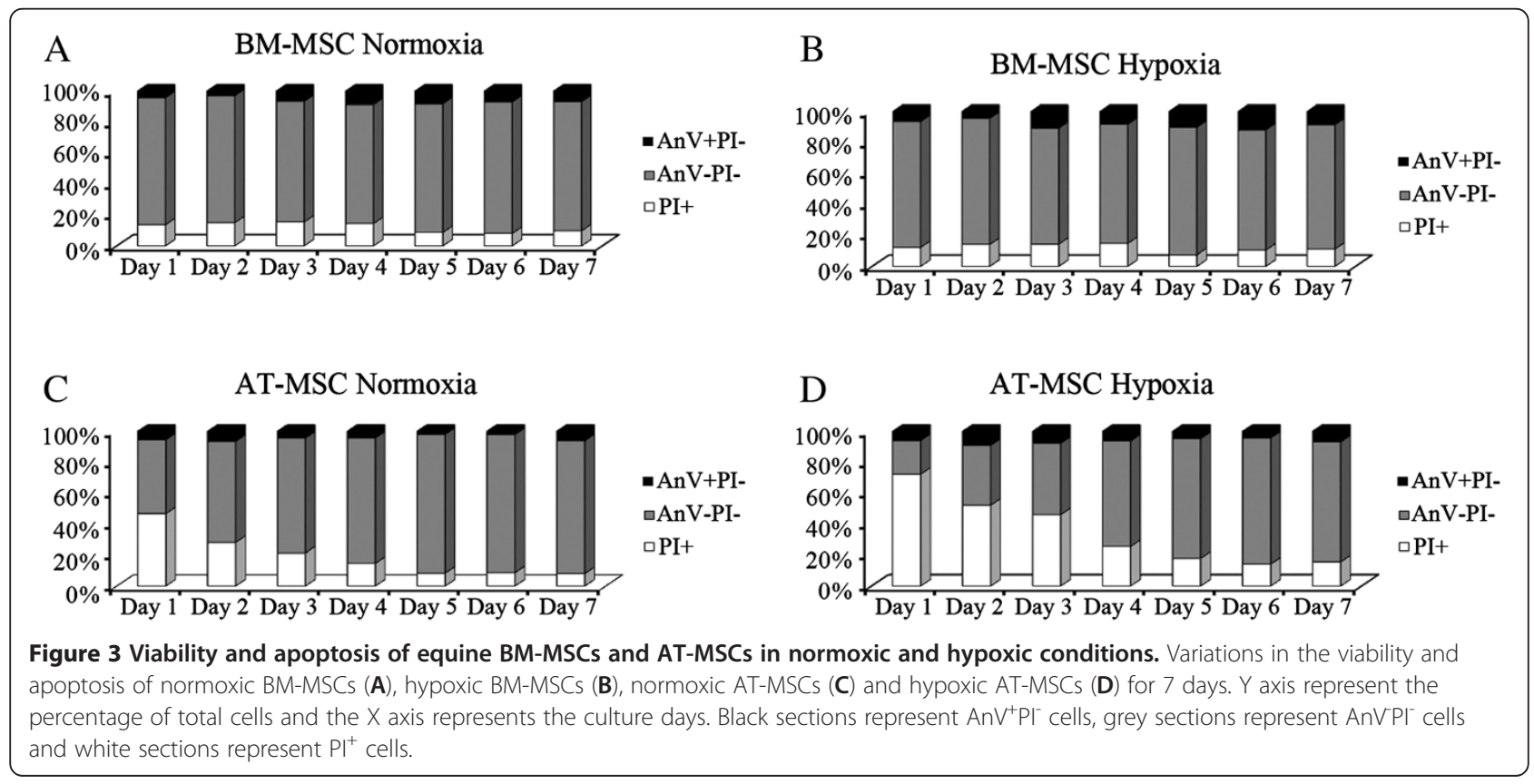


Table 2 Viability of BM-MSCs $(n=6)$ and AT-MSCs $(n=6)$ cultured under hypoxic or normoxic conditions

\begin{tabular}{|c|c|c|c|c|c|c|c|c|c|}
\hline & \multicolumn{2}{|c|}{ A } & \multicolumn{2}{|c|}{ B } & \multicolumn{2}{|c|}{ C } & \multicolumn{2}{|c|}{ D } \\
\hline & & \multicolumn{2}{|c|}{ BM-MSC } & \multicolumn{2}{|c|}{ AT-MSC } & \multicolumn{2}{|c|}{ Normoxia } & \multicolumn{2}{|c|}{ Hypoxia } \\
\hline & & Normoxia & Hypoxia & Normoxia & Hypoxia & BM-MSC & AT-MSC & BM-MSC & AT-MSC \\
\hline \multirow[t]{3}{*}{ Day 1} & $\mathrm{PI}^{+}$ & $13.64 \pm 2,03$ & $12.06 \pm 3.89$ & $46.64 \pm 26.38$ & $72.24 \pm 17.20$ & $13.64 \pm 2,03^{a}$ & $46.64 \pm 26.38^{b}$ & $12.06 \pm 3.89^{\mathrm{a}}$ & $72.24 \pm 17.20^{b}$ \\
\hline & $\mathrm{AnVPl}^{-}$ & $81.92 \pm 2.74$ & $81.39 \pm 8.51$ & $47.86 \pm 23.61^{a}$ & $21.79 \pm 12.35^{b}$ & $81.92 \pm 2.74^{\mathrm{a}}$ & $47.86 \pm 23.61^{b}$ & $81.39 \pm 8.51^{a}$ & $21.79 \pm 12.35^{b}$ \\
\hline & $\mathrm{AnV}^{+} \mathrm{Pl}^{-}$ & $4.44 \pm 1.27$ & $6.52 \pm 4.94$ & $5.60 \pm 2.69$ & $6.05 \pm 6.04$ & $4.44 \pm 1.27$ & $5.60 \pm 2.69$ & $6.52 \pm 4.94$ & $6.05 \pm 6.04$ \\
\hline \multirow[t]{3}{*}{ Day 2} & $\mathrm{Pl}^{+}$ & $15,02 \pm 3.05$ & $13,97 \pm 6.37$ & $28.01 \pm 11.11$ & $52.85 \pm 25.16$ & $15,02 \pm 3.05^{\mathrm{a}}$ & $28.01 \pm 11.11^{b}$ & $13,97 \pm 6.37^{a}$ & $52.85 \pm 25.16^{b}$ \\
\hline & $\mathrm{AnVPl}^{-}$ & $81.91 \pm 3.67$ & $81.72 \pm 7.00$ & $65.45 \pm 12.05^{a}$ & $39.31 \pm 22.23^{b}$ & $81.91 \pm 3.67^{\mathrm{a}}$ & $65.45 \pm 12.05^{b}$ & $81.72 \pm 7.00^{a}$ & $39.31 \pm 22.23^{b}$ \\
\hline & $\mathrm{AnV}^{+} \mathrm{Pl}^{-}$ & $3.07 \pm 0.94$ & $4.53 \pm 1.52$ & $6.54 \pm 2.53$ & $9.31 \pm 5.23$ & $3.07 \pm 0.94^{a}$ & $6.54 \pm 2.53^{b}$ & $4.53 \pm 1.52$ & $9.31 \pm 5.23$ \\
\hline \multirow[t]{3}{*}{ Day 3} & $\mathrm{Pl}^{+}$ & $15.44 \pm 7.98$ & $14.07 \pm 5.08$ & $21,29 \pm 3.94^{a}$ & $45.97 \pm 19.78^{b}$ & $15.44 \pm 7.98$ & $21,29 \pm 3.94$ & $14.07 \pm 5.08^{a}$ & $45.97 \pm 19.78^{b}$ \\
\hline & $\mathrm{AnVPI}^{-}$ & $77.84 \pm 3.96$ & $75.04 \pm 11.65$ & $74.28 \pm 3.13^{a}$ & $46.24 \pm 18.6^{b}$ & $77.84 \pm 3.96^{a}$ & $74.28 \pm 3.13^{b}$ & $75.04 \pm 11.65^{a}$ & $46.24 \pm 18.61^{b}$ \\
\hline & $\mathrm{AnV}^{+} \mathrm{Pl}^{-}$ & $6.71 \pm 2.16$ & $10.86 \pm 7.19$ & $4.43 \pm 1.62$ & $7.83 \pm 5.23$ & $6.71 \pm 2.16$ & $4.43 \pm 1.62$ & $10.86 \pm 7.19$ & $7.83 \pm 5.23$ \\
\hline \multirow[t]{3}{*}{ Day 4} & $\mathrm{Pl}^{+}$ & $14.43 \pm 6.25$ & $14.60 \pm 7.41$ & $14.64 \pm 3.60^{\mathrm{a}}$ & $25.39 \pm 11.67^{b}$ & $14.43 \pm 6.25$ & $14.64 \pm 3.60$ & $14.60 \pm 7.41^{a}$ & $25.39 \pm 11.67^{b}$ \\
\hline & $\mathrm{AnVPI}^{-}$ & $76.82 \pm 5.89$ & $77.11 \pm 7.49$ & $80.98 \pm 2.88$ & $68.31 \pm 11.32$ & $76.82 \pm 5.89$ & $80.98 \pm 2.88$ & $77.11 \pm 7.49$ & $68.31 \pm 11.32$ \\
\hline & $\mathrm{AnV}^{+} \mathrm{Pl}^{-}$ & $8.74 \pm 4.06$ & $8.31 \pm 3.15$ & $4.41 \pm 2.40$ & $6.30 \pm 5.49$ & $8.74 \pm 4.06^{a}$ & $4.41 \pm 2.40^{b}$ & $8.31 \pm 3.15$ & $6.30 \pm 5.49$ \\
\hline \multirow[t]{3}{*}{ Day 5} & $\mathrm{Pl}^{+}$ & $8.7 \pm 3.27$ & $7.34 \pm 2.61$ & $8.29 \pm 1.80^{a}$ & $17.82 \pm 7.72^{b}$ & $8.7 \pm 3.27$ & $8.29 \pm 1.80$ & $7.34 \pm 2.61^{a}$ & $17.82 \pm 7.72^{b}$ \\
\hline & $\mathrm{AnV}^{-\mathrm{Pl}^{-}}$ & $83.03 \pm 4.91$ & $82.28 \pm 8.29$ & $89.64 \pm 1.54^{a}$ & $77.37 \pm 6.67^{b}$ & $83.03 \pm 4.91^{a}$ & $89.64 \pm 1.54^{b}$ & $82.28 \pm 8.29^{a}$ & $77.37 \pm 6.67^{b}$ \\
\hline & $\mathrm{AnV}^{+} \mathrm{Pl}^{-}$ & $8.28 \pm 3.49$ & $10.37 \pm 7.60$ & $2.06 \pm 0.73$ & $4.81 \pm 4.22$ & $8.28 \pm 3.49^{a}$ & $2.06 \pm 0.73^{b}$ & $10.37 \pm 7.60$ & $4.81 \pm 4.22$ \\
\hline \multirow[t]{3}{*}{ Day 6} & $\mathrm{PI}^{+}$ & $8.04 \pm 4.37$ & $10.27 \pm 1.59$ & $8.64 \pm 1.51$ & $14.14 \pm 8,83$ & $8.04 \pm 4.37$ & $8.64 \pm 1.51$ & $10.27 \pm 1.59$ & $14.14 \pm 8,83$ \\
\hline & $\mathrm{AnV}^{-} \mathrm{Pl}^{-}$ & $84.79 \pm 7.37$ & $77.76 \pm 9.44$ & $89.18 \pm 1.32$ & $81.43 \pm 10.06$ & $84.79 \pm 7.37$ & $89.18 \pm 1.32$ & $77.76 \pm 9.44$ & $81.43 \pm 10.06$ \\
\hline & $\mathrm{AnV}^{+} \mathrm{PI}^{-}$ & $7.16 \pm 3.46$ & $11.98 \pm 7.96$ & $2.14 \pm 0.66$ & $4.42 \pm 2.71$ & $7.16 \pm 3.46^{a}$ & $2.14 \pm 0.66^{b}$ & $11.98 \pm 7.96$ & $4.42 \pm 2.71$ \\
\hline \multirow[t]{3}{*}{ Day 7} & $\mathrm{Pl}^{+}$ & $9.77 \pm 5,27$ & $10.95 \pm 4.29$ & $8.05 \pm 4.28^{\mathrm{a}}$ & $15.69 \pm 8.96^{b}$ & $9.77 \pm 5,27$ & $8.05 \pm 4.28$ & $10.95 \pm 4.29$ & $15.69 \pm 8.96$ \\
\hline & $\mathrm{AnVPI}^{-}$ & $83.29 \pm 6.91$ & $80.45 \pm 5.98$ & $85.67 \pm 7.91$ & $78.05 \pm 7.77$ & $83.29 \pm 6.91$ & $85.67 \pm 7.91$ & $80.45 \pm 5.98$ & $78.05 \pm 7.77$ \\
\hline & $\mathrm{AnV}^{+} \mathrm{Pl}^{-}$ & $6.92 \pm 3.40$ & $8.65 \pm 7.26$ & $6.14 \pm 4.32$ & $6.96 \pm 1.16$ & $6.92 \pm 3.40$ & $6.14 \pm 4.32$ & $8.65 \pm 7.26$ & $6.96 \pm 1.16$ \\
\hline
\end{tabular}

Viability data are represented as the mean \pm standard deviation. Non-viable cells $\left(\mathrm{PI}^{+}\right)$, viable cells $\left(\mathrm{AnV}^{-} \mathrm{PI}^{-}\right)$and apoptotic cells $\left(\mathrm{AnV}^{+} \mathrm{PI}^{-}\right)$were analysed for 7 days. Superscripted bold data ("a" and "b") are significantly different. (A) Compares normoxic and hypoxic conditions of BM-MSCs; (B) compares normoxic and hypoxic conditions of AT-MSCs; (C) compares BM-MSCs and AT-MSCs in normoxic conditions; and (D) compares BM-MSCs and AT-MSCs in hypoxic conditions.

that were expanded in different oxygen conditions. The expression of the CD49d gene was significantly higher in normoxic BM-MSCs than in their hypoxic counterparts. In AT-MSCs, CD44 expression was significantly higher in normoxia.

Further differences in gene expression were observed when cultures from different sources exposed to the same oxygen tension were compared. In general, there was a trend of higher gene expression for all surface

Table 3 Immunophenotype of BM-MSCs and AT-MSCs cultured under normoxic and hypoxic conditions

\begin{tabular}{lcc}
\hline & CD29 & CD90 \\
\hline BM-MSC Normoxia & $99.73 \pm 0.03$ & $97.40 \pm 0.66$ \\
BM-MSC Hypoxia & $99.41 \pm 0.26$ & $98.06 \pm 0.60$ \\
AT-MSC Normoxia & $97.93 \pm 0.83$ & $96.52 \pm 1.01$ \\
AT-MSC Hypoxia & $98.75 \pm 1.33$ & $93.65 \pm 3.92$ \\
\hline
\end{tabular}

Data are expressed as the mean \pm standard deviation of percentages of MSCs positive for CD29 and CD90 expression. The expression data were obtained using flow cytometry. markers analysed in AT-MSCs, being statistically significant for CD44, CD90 and CD105 in normoxia and CD44, CD29, CD34, CD90 and CD146 in hypoxia. A tendency of a higher expression in BM-MSCs was detected for CD49d in normoxia, and CD106 in both normoxic and hypoxic conditions. Similar gene expression patterns of the surface antigens CD73 and CD166 were detected in the four conditions (two types of cells grown under two oxygen treatments). Although the level of CD106 mRNA was very low in hypoxic AT-MSCs, any significant differences existed between the two tissue sources and oxygen conditions.

\section{Hipoxia inducible factor $1 a$ and pluripotency markers}

The gene expression of $H I F-1 \alpha$ and pluripotency markers was measured in both normoxic and hypoxic cells using RT-qPCR.

Gene expression of $H I F-1 \alpha$ was detected in BM-MSCs and AT-MSCs in both oxygen conditions (Figure 5A). The mRNA levels were higher in hypoxic MSCs than in normoxic MSCs derived from the two sources, being 


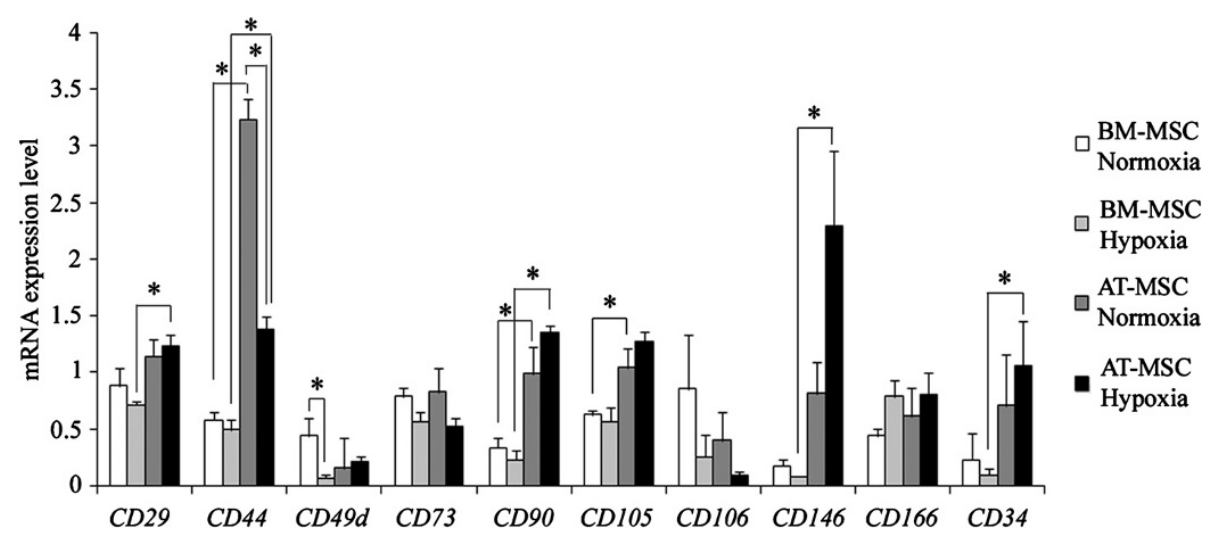

Figure 4 Gene expression of $C D 29, C D 34, C D 44, C D 49 d, C D 73, C D 90, C D 105, C D 106, C D 146$ and $C D 166$ cell surface markers of equine MSCs. Relative mRNA expression levels are expressed as the mean \pm standard error. White bars correspond to normoxic BM-MSCs $(n=6)$, light grey bars with hypoxic BM-MSCs $(n=6)$, dark grey bars with normoxic AT-MSCs $(n=6)$ and black bars with hypoxic AT-MSCS $(n=6)$. $\left({ }^{*} P<0.05\right)$.

statistically significant for AT-MSCs. BM-MSCs and AT-MSCs expressed similar levels of HIF-1 $\alpha$ for each oxygen condition.

Transcripts of the embryonic stem cell makers OCT4, NANOG and SOX2 were detected in BM-MSCs and AT-
MSCs expanded in both oxygen conditions (Figure 5B-D). The mRNA levels were consistently higher in AT-MSCs than in BM-MSCs, with statistically significant differences for the gene expression of OCT4 in hypoxia and NANOG in normoxia.

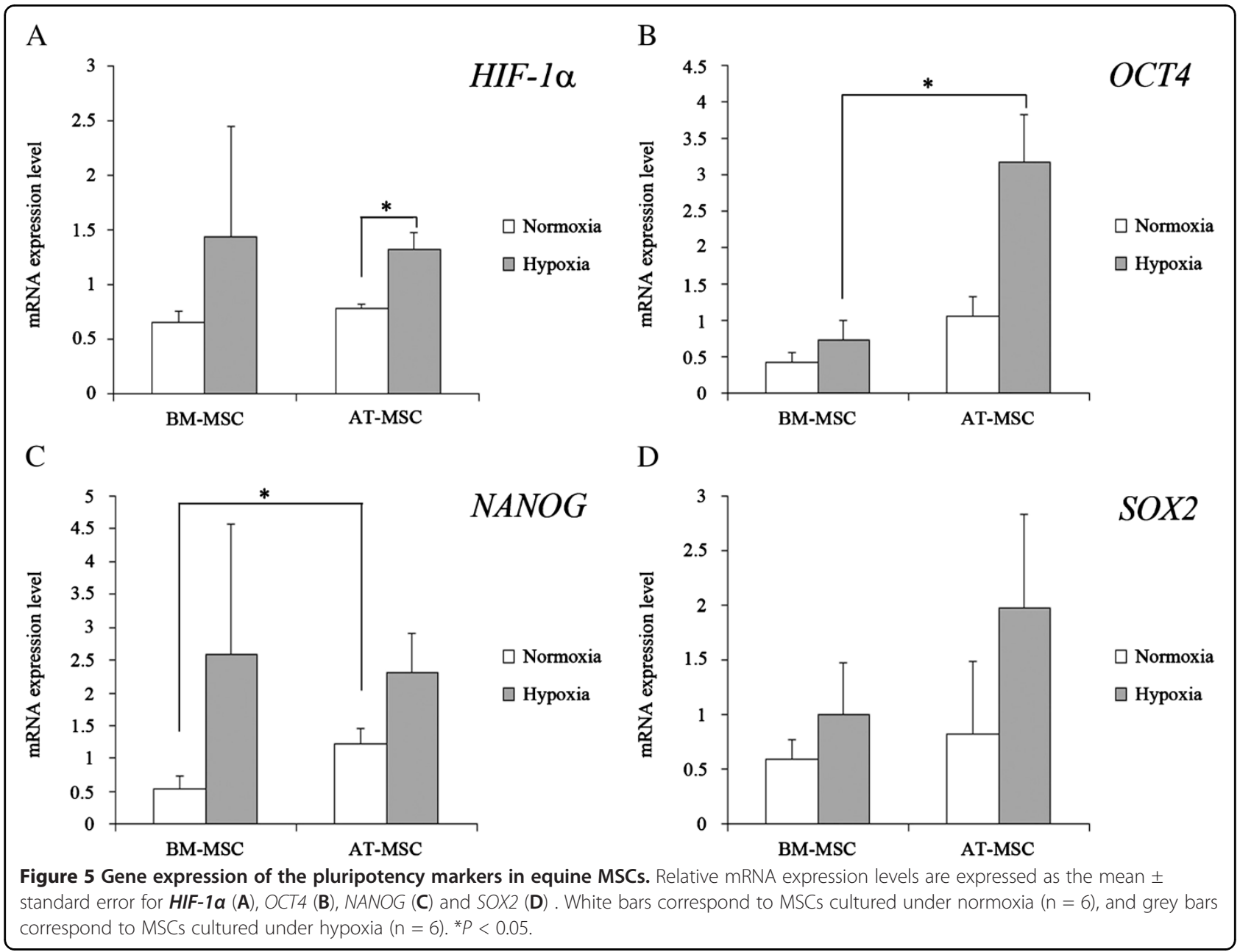


The MSCs exposed to $5 \% \mathrm{O}_{2}$ showed a tendency to express higher levels of the three genes than the MSCs exposed to $20 \% \mathrm{O}_{2}$.

\section{Discussion}

In the equine veterinary field, orthopaedic injuries are a major cause of retirement of athletic horses [17]. As a result, it is not surprising that equine regenerative medicine is primarily focused on the treatment of musculoskeletal defects. The present cell therapy studies are carried out with MSCs [12,13,18] and non-adult stem cells [19-21]. To better understand the mechanisms of action of MSCs in vivo, a large number of studies to characterise equine MSCs have been reported over the last five years [22-26]. However, because the overall objective of regenerative treatments is the use of MSCs in live horses, it is important to determine all of the properties of MSCs in an oxygen environment that closely emulates the original physiological niche from which the cells derive. To our knowledge, the current work constitutes the first study to perform an analysis of the influence of oxygen tension on proliferation, viability, stemness and marker expression in equine MSCs derived from bone marrow and adipose tissue.

The effects of hypoxia on MSC proliferation have been studied specifically in humans and mice. Enhancements in cell growth following exposure to hypoxia have been described [10,11,27]. However, there is no unanimous consent, Feher et al. (2010) reported no difference in the growth of normoxic and hypoxic cells, and Volker et al. (2010) described similar numbers of cells for both oxygen conditions at the conclusion of the culture period. In addition, Holzwarth et al. (2010), Zeng et al. (2011) and Wang et al. (2005) reported that low oxygen tension inhibited the proliferation of MSCs. Similarly, canine MSCs derived from bone marrow and adipose tissue exposed to atmospheric $\mathrm{O}_{2}$ show more proliferative capacity than those expanded from passage 1 to passage 3 under hypoxic conditions $\left(1 \%\right.$ or $\left.5 \% \mathrm{O}_{2}\right)$ [28]. In agreement with these findings, our results describing the proliferation of equine cells as a function of oxygen tension showed that the growth of AT-MSCs was significantly higher at atmospheric oxygen tension, while BM-MSCs underwent also more proliferation in $20 \% \mathrm{O}_{2}$.

Differences in cell growth between cultures expanded under different oxygen conditions could result from cell cycle changes or alterations of cell viability. Human MSC populations derived from umbilical cord and bone marrow accumulate cells in $G_{0} / G_{1}$ phase under low oxygen tension [9,29]. Similar to these experiments, we found that hypoxic BM-MSCs displayed a higher percentage of cells in $G_{0} / G_{1}$ phases than normoxic BM-MSCs throughout the entire culture period. Moreover, the significantly higher proportion of normoxic BM-MSCs involved in the active stages of cell division ( $S$ or $G_{2} / M$ ) during the median days of culture led to a higher number of BM-MSCs at the conclusion of proliferation assay in the normoxic culture. Cellular arrest in $G_{0} / G_{1}$ phase in hypoxic BM-MSCs might be caused by up-regulation of cyclin-dependent kinase inhibitors that control the cell cycle checkpoint [30-32].

In contrast to BM-MSCs, differences observed in the proliferation of normoxic and hypoxic AT-MSC cultures were not due to cell cycle variations, but to variations in cell viability. Similarly to rat MSCs, that undergo a reduction in cell viability when permanently exposed to hypoxia [33], in our work the proportions of viable AT-MSCs in hypoxic cultures were always lower than those in normoxic cultures. Reduced viability in hypoxic conditions reflects insufficient adaptation of AT-MSCs at $5 \% \mathrm{O}_{2}$, as higher percentages of nonviable cells were found in hypoxic conditions relative to populations at $20 \% \mathrm{O}_{2}$. No detectable changes in apoptosis have been previously described for hypoxic MSCs [34,35]; our results corroborate these reports since the proportion of $\mathrm{AnV}^{+} \mathrm{PI}^{-}$did not display statistical differences between normoxic and hypoxic MSCs derived from the same source.

Moreover, AT-MSCs under either oxygen tension adapted more poorly to the culture environment following trypsinisation than BM-MSCs, as shown by a significantly higher proportion of $\mathrm{PI}^{+}$AT-MSCs at days 1 and 2 for both $5 \%$ and $20 \% \mathrm{O}_{2}$ atmospheres. This is reflected in the increased lag phase displayed by AT-MSCs. However, AT-MSCs also showed a significantly increased proportion of cells undergoing cell division during the first days of culture. The increase in cell division of viable AT-MSCs might compensate for cell death in the population because the final number of cells obtained at the end of the experiment was higher in AT-MSC cultures than in BM-MSC cultures, which indicates a higher proliferative ability for AT-MSCs than BM-MSCs. This result is in agreement with previous reports in horses [26] and other species as canine [28], rat [36] and human [37], which demonstrated AT-MSCs proliferated more rapidly than BM-MSC. In our experimental conditions, AT-MSCs in normoxic condition did not display a plateau phase in the proliferation curve and, at the light microscope, AT-MSCs start growing in several layers instead of an only monolayer (data not shown). These observations might point out a lack of contact inhibition of growth in AT-MSCs. In addition, in a previous study, we described the more rapid decrease of apoptosis in AT-MSCs compared with BM-MSCs in cultures at 20\% $\mathrm{O}_{2}$ using a limited number of animals $(\mathrm{n}=2)$ [26]. The current study confirms that finding because normoxic 
AT-MSCs showed significantly lower proportion of apoptotic cells than normoxic BM-MSCs.

Flow cytometric immunophenotype analysis of horse MSCs revealed that the surface antigen CD90 was detectable in all MSC types [38-41]. In addition, cross-reactivity with human antibodies has been demonstrated for the CD29 antigen in a previous report from our group and also in other studies [42,43]. Because in other species hypoxia does not alter the immunophenotype of MSCs with regard to CD29 [29] and CD90 [9,27,44], we attempted to characterise this phenotype in equine MSCs and to analyse the presence of these molecules in both BM-MSCs and ATMSCs in hypoxia and normoxia. According to the literature, equine MSCs displayed the same immunophenotype for CD29 and CD90 independently of the cell source and oxygen tension.

The lack of immunoreactivity of commercial antibodies with equine MSC antigens remains a challenge in determining the immunophenotype of these cells by flow cytometry. As a supplement to this technique, RT-qPCR has been used to establish the expression profiles of various cell surface markers in equine MSCs [39,42]. Similar gene expression patterns were demonstrated in ATMSCs when they were compared to BM-MSCs in their respective oxygen conditions. AT-MSCs at both oxygen tensions expressed higher levels of CD29, CD44, CD90, CD146 and CD34 transcripts respect to BM-MSCs; in contrast, only normoxic AT-MSCs expressed lower mRNA levels of CD49d compared to normoxic BMMSCs. These results are in agreement with our previous report [43]. The differences in CD105 expression, with respect to our previous work, might be due to individual differences because different animals were used in the present study. Hypoxia seemed to significantly modify mRNA levels of CD49d in BM-MSCs and CD44 in AT-MSCs, which is in agreement with other studies that have described different expression profiles for CD49d [45] and CD44 [46] in hypoxia. The remaining surface markers analysed in this study showed similar gene expression pattern at the different oxygen conditions studied.

HIF- $1 \alpha$ is a transcription factor that is expressed constitutively in cells, although is ubiquitinated and degraded under normoxic conditions. In our study, the gene expression of this factor was detected in normoxic and hypoxic cultures, although HIF-1 $\alpha$ was up-regulated in cultures exposed to low oxygen tension.

The expression of specific markers characteristic of embryonic stem cells have been described before for equine BM-MSCs [47] and AT-MSCs [40]. However, to our knowledge, this is the first work that compares the gene expression of the pluripotency markers OCT4, NANOG and SOX2 in equine AT-MSCs and BM-MSCs that were exposed to different oxygen concentrations. In our experimental conditions, equine MSCs expressed all three pluripotency markers. In general, higher expression of each marker was detected in AT-MSCs and was statistically significant for OCT4 in hypoxia and for NANOG in normoxia. The consistently higher expression of all genes in hypoxia might reflect the enhanced stemness of hypoxic equine MSCs [48]. These results agree with other studies that have described up-regulation of pluripotency-associated markers of hypoxic MSCs $[11,49,50]$. To our knowledge the relationship between pluripotency markers and HIF-1 $\alpha$ has never been investigated in MSCs. However, studies in cancer cells have revealed the expression of HIF- $1 \alpha$ induces a gene expression increase of genes involved in stemness [51]; in accordance with this, the higher expression of HIF-1 $\alpha$ observed in hypoxic cultures of equine MSCs could enhance the gene expression of the pluripotency markers. Taken together, the results might suggest that low oxygen tension helps maintain the undifferentiated stem cell phenotype.

\section{Conclusions}

Oxygen plays a deterministic role in equine MSC cultures. It is able to modify their proliferative capacity via cell cycle modification in BM-MSCs and alterations in cell viability in AT-MSCs. Moreover, the immunophenotype of both MSC types is not altered by hypoxia. However, hypoxia appears to be an important factor in the maintenance or acquisition of stemness in equine MSCs.

\section{Methods \\ Animals}

In order to work with a homogeneous group of animals to reduce the interindividual differences derived from age, breed or sex, biological samples were obtained from a total of 12 castrated male horses aged from 4 to 7 years. All procedures were carried out under Project Licence PI36/07, which was approved by the Ethic Committee for Animal Experiments from the University of Zaragoza. The care and use of animals were performed in accordance with the Spanish Policy for Animal Protection RD1201/05, which meets the European Union Directive $86 / 609$ on the protection of animals for experimental and other scientific purposes.

\section{MSC isolation, culture and expansion}

Samples were collected as previously described [26,43]. Briefly, bone marrow aspirates were harvested from the sternum of six horses. The mononuclear fractions were enriched with MSCs, which were isolated in a centrifugation gradient using Lymphoprep (Atom, Barcelona, Spain). Isolated MSCs were rinsed twice with PBS and 
plated at a concentration of $10^{6}$ cells $/ \mathrm{cm}^{2}$ in growth medium, which consisted of DMEM Low Glucose (Sigma-Aldrich, St. Louis, Missouri, USA) supplemented with foetal bovine serum, L-glutamine (Sigma-Aldrich, St. Louis, Missouri, USA) and penicillin/streptomycin (Sigma-Aldrich, St. Louis, Missouri, USA).

Subcutaneous adipose tissues were collected from the dorsal gluteal muscle below the tail from six horses. The stromal vascular fractions (SVFs) were isolated by digestion with $0.01 \%$ collagenase (Type I, Sigma-Aldrich, St.
Louis, Missouri, USA) for $30 \mathrm{~min}$ at $37^{\circ} \mathrm{C}$ with continuous shaking. The cells were rinsed twice with PBS and plated in growth medium at a concentration of $10^{5}$ cells $/ \mathrm{cm}^{2}$.

Both MSC types were expanded for 4 weeks at $37^{\circ} \mathrm{C}$ in either normoxic $\left(5 \% \mathrm{CO}_{2}\right.$ and $20 \% \mathrm{O}_{2}$ ) or hypoxic $(5 \%$ $\mathrm{CO}_{2}$ and $5 \% \mathrm{O}_{2}$ ) conditions. Cell growth kinetics, immunophenotype, viability and cell cycle analyses were carried out using newly passaged cells fresh cells. Aliquots of $10^{6}$ cells were preserved at $-150^{\circ} \mathrm{C}$ at the final passage, as described above, for further gene expression studies.

Table 4 Summary of gene information

\begin{tabular}{|c|c|c|c|}
\hline Gene & $\begin{array}{l}\text { Accession } \\
\text { number }\end{array}$ & Primer sequence $\left(5^{\prime}-3^{\prime}\right)$ & $\begin{array}{l}\text { Amplicon } \\
\text { size (bp) }\end{array}$ \\
\hline \multirow[t]{2}{*}{$\mathrm{CD} 29^{\mathrm{a}}$} & XM_001492665 & F: GTAAAAAGTCTTGGAACCGATCTGAT & 81 \\
\hline & & R: CACAAATGAGCCAAACCCAATT & \\
\hline \multirow[t]{2}{*}{$\operatorname{CD} 34^{\mathrm{a}}$} & XM_001491596 & F:CACTAAACCCTCTACATCATTTTCTCCTA & 150 \\
\hline & & R: GGCAGATACCTTGAGTCAATTTCA & \\
\hline \multirow[t]{2}{*}{$C D 44^{a}$} & NM_001085435 & F: CCCACGGATCTGAAACAAGTG & 95 \\
\hline & & R: TTCTGGAATTTGAGGTCTCCGTAT & \\
\hline \multirow[t]{2}{*}{ CD49d ${ }^{\mathrm{a}}$} & XM_001917601 & F: CATCGGCCTTCTCACAGAGAA & 101 \\
\hline & & R: GCCATTATTGTCTGCATCAATTTG & \\
\hline \multirow[t]{2}{*}{$C D 73^{a}$} & XM_001500115 & F: GGGATTGTTGGATACACTTCAAAAG & 90 \\
\hline & & R: GCTGCAACGCAGTGATTTCA & \\
\hline \multirow[t]{2}{*}{$\operatorname{CD} 90^{\mathrm{a}}$} & EU881920 & F: TGCGAACTCCGCCTCTCT & 93 \\
\hline & & R: GCTTATGCCCTCGCACTTG & \\
\hline \multirow[t]{2}{*}{ CD105 ${ }^{a}$} & XM_001500078 & F: GACGGAAAATGTGGTCAGTAATGA & 100 \\
\hline & & R: GCGAGAGGCTCTCCGTGTT & \\
\hline \multirow[t]{2}{*}{$\mathrm{CD}_{106}{ }^{\mathrm{a}}$} & NM_001101650 & F: CATCGTGACCTGTGGGCATA & 111 \\
\hline & & R: TGGGTITCCCTCCACTAGCA & \\
\hline \multirow[t]{2}{*}{$C D 146^{\mathrm{a}}$} & XM_001917594 & F: CTGGACTTGGAAACCACAACATC & 85 \\
\hline & & R: CAGGTCTCACTCGGACATCAGA & \\
\hline \multirow[t]{2}{*}{ CD166 ${ }^{\mathrm{a}}$} & XM_001503380 & F: GTCTGGTCTTCTGCCTCTTGATC & 103 \\
\hline & & R: TCGGCAAGGCATGATAATAGTG & \\
\hline \multirow[t]{2}{*}{$H I F-1 a$} & XM_001493206 & F: AATCCAAAGATCCTGGCGTTG & 103 \\
\hline & & R: GCTGCTGTAGTAATGCGCCAAT & \\
\hline \multirow[t]{2}{*}{ OCT4 ${ }^{\mathrm{b}}$} & XM_001490108 & F: AGAGGCAACCTGGAGAACATG & 70 \\
\hline & & R: GGGCAATGTGGCTGATCTG & \\
\hline \multirow[t]{2}{*}{ NANOG ${ }^{\mathrm{b}}$} & XM_001498808 & F: TACCTCAGCCTCCAGCAGAT & 119 \\
\hline & & R: CAGTTGTTITTCTGCCACCT & \\
\hline \multirow[t]{2}{*}{$\mathrm{SO} \times 2^{\mathrm{c}}$} & FJ356148 & F: TGGTTACCTCTTCCTCCCACT & 178 \\
\hline & & R: GGGCAGTGTGCCGTTAAT & \\
\hline \multirow[t]{2}{*}{$G A P D H^{a}$} & NM_001163856 & F: GGCAAGTTCCATGGCACAGT & 128 \\
\hline & & R: CACAACATATTCAGCACCAGCAT & \\
\hline \multirow[t]{2}{*}{$B 2 M^{a}$} & NM_001082502 & F: TCGTCCTGCTCGGGCTACT & 102 \\
\hline & & R: ATTCTCTGCTGGGTGACGTGA & \\
\hline
\end{tabular}

${ }^{a}$ previously described in [43]

${ }^{b}$ previously described in [40].

c previously described in [47].

Genes analysed, GenBank accession numbers, primer sequences for reverse transcriptase RT-PCR (F: forward and R: reverse) and amplicon sizes in base pairs (bp). 


\section{Cell growth kinetics}

Cells from bone marrow and adipose tissue were seeded in 6-well plates in triplicate at a density of 5,000 cells/ $\mathrm{cm}^{2}$. BM-MSCs $(\mathrm{n}=6)$ and AT-MSCs $(\mathrm{n}=6)$ were exposed to $20 \% \mathrm{O}_{2}$ or $5 \% \mathrm{O}_{2}$ atmospheres for 7 days. Every day, the cells were collected using $0.25 \%$ trypsin/ EDTA, and an aliquot of $50 \mu \mathrm{L}$ of each culture was counted in a haemocytometer Z2 Coulter particle count and size analyser to obtain growth curves.

\section{Analysis of cellular DNA content}

Half of the MSCs harvested from the proliferation assay were fixed in $70 \%$ ice-cold ethanol and treated with $0.02 \mathrm{mg} / \mathrm{mL}$ RNAse and EDTA. DNA was stained with $0.1 \mathrm{mg} / \mathrm{mL}$ propidium iodide (Sigma-Aldrich, St. Louis, Missouri, USA). Cells were incubated in the dark for $30 \mathrm{~min}$, and samples were analysed on a FACSARRAY (BD Biosciences, East Rutherford, New Jersey, USA) cytometer using the MODIFIT 3.0 software.

\section{Viability assay}

The remaining fraction of MSCs harvested in the proliferation assay was used to determine MSC viability. Apoptosis was measured by the detection of phosphatidylserine on the outer leaflet of the plasma membrane with the fluorescent dye Annexin V-FITC (Immunostep, Salamanca, Spain) in accordance with the manufacturer's instructions. Briefly, cells were rinsed with ice-cold PBS and then resuspended in $200 \mu \mathrm{L}$ of binding buffer. Subsequently, $10 \mu \mathrm{L}$ of Annexin V stock solution was added to cells and incubated for $30 \mathrm{~min}$ at $4^{\circ} \mathrm{C}$. Non-viable cells were identified by incubation with $5 \mu \mathrm{L}$ of propidium iodide, a dye that penetrates into the cell nucleus when the plasma and nuclear cell membranes are damaged. PIstained cells were immediately analysed in a FACSARIA cytometer (BD Biosciences, East Rutherford, New Jersey, USA) using FACSDIVA 5.0.1 software.

\section{Immunophenotyping}

To determine the immunophenotype of BM-MSCs and AT-MSCs after hypoxic and normoxic culture, the expression of the MSC surface markers CD29 (Integrin $\beta 1$ ) and CD90 (Thy-1) was assessed by flow cytometry as previously described [43] using mouse anti-human monoclonal antibodies CD29-FITC (Caltag Laboratories, Little Balmer, Buckingham, UK) and CD90-PE (BD Pharmingen, San Diego, California, USA.). Negative control staining was performed using a FITC-conjugated mouse IgG1 isotype and a PE-conjugated mouse isotype. The immunophenotype was determined with the cytometer and software described above.

\section{Gene expression analysis}

The expression of 10 genes encoding cell surface molecules, including $C D 29$ and $C D 90$, was determined by real-time quantitative PCR. Additional antigens examined were CD34, CD44 (H-CAM), CD49d ( $\alpha 4$ integrin), CD73 (ecto-5'-nuclease), CD105 (endoglin), CD106 (VCAM 1), CD146 (MCAM) and CD166 (ALCAM). The gene expression levels of the pluripotency markers OCT4, SOX2 and NANOG were also analysed using the same technique.

Total RNA was extracted using the RNA spin mini (GE Healthcare Lifesciences, Little Chalfont, UK) and DNAse turbo (Ambion, Foster City, California, USA.) kits; subsequently, the Superscript kit (Invitrogen, Carlsbad, CA, USA ) was used for reverse transcription of $1.5 \mu \mathrm{g}$ of total RNA into complementary DNA. All kits were used in accordance with the manufacturer's instructions.

Table 4 shows the names of the analysed genes, GenBank accession numbers for equine mRNA sequences, forward and reverse primer sequences and amplicon sizes. Amplifications were performed in triplicate using the Fast SYBR Green Master Mix reagent (Applied Biosystems, Foster City, California, USA) and the StepOne ${ }^{\mathrm{m}}$ Real Time System (Applied Biosystems, Foster City, California, USA). The levels of gene expression were determined using the comparative $\mathrm{Ct}$ method. A normalisation factor was calculated as the geometric mean of the quantity of two housekeeping genes (GAPDH and $B 2 M)$ and used to normalise the expression of each gene.

\section{Statistical analyses}

The software SPSS 19.0 (Armonk, Nueva York, USA) was used to perform statistical analyses. Data obtained from flow cytometry and RT-qPCR were analysed for normality with the Shapiro-Wilk test. Differences in gene expression and reactivity levels in BM- and ATMSCs expanded under hypoxia and normoxia conditions were determined using unpaired non-parametric MannWhitney tests. Differences in proliferation, viability and cell cycle were evaluated with Student's $t$-test. For both tests, $P<0.05$ was considered statistically significant.

\section{Abbreviations}

MSC: Mesenchymal stem cell; BM-MSC: Bone marrow-derived mesenchymal stem cell; AT-MSC: Adipose tissue-derived mesenchymal stem cell;

AnV: Annexin V; PI: Propidium iodide; $\mathrm{AnV}^{+} \mathrm{Pl}^{-}$: Apoptotic cells; $\mathrm{Pl}^{+}$: Non-viable cells; AnVPI': Viable cells; RT-qPCR: Real time quantitative PCR.

\section{Competing interests}

The authors declare that they have no competing interests.

\section{Authors' contributions}

BR carried out the expansion of the cells, proliferation assays, gene expression analyses, statistical analysis and drafted the manuscript. ARR participated in the expansion of the cells and proliferation assays. SAA participated in the gene expression analyses. AR performed the sample collections from the horses. FJV participated in the sample collections from the horses. PZ helped to draft the manuscript. IMB conceived the study, 
participated in its design and helped to draft the manuscript. CR conceived the study, participated in its design and helped to draft the manuscript. All authors read and approved the final manuscript.

\section{Acknowledgements}

We thank Javier Godino from the Cell Separation Service of the Instituto Aragonés de Ciencias de la Salud (I + CS) for his technical assistance with the immunophenotyping experiments, cell cycle determination and viability assays. This work was performed as part of the AGL2008- 02428/GAN (MICINN/FEDER) and PAMER Pipamer 09/019 projects and was partially financed by the Gobierno de Aragón (Grupo de Excelencia LAGENBIO) and Instituto Aragonés de Ciencias de la Salud (I + CS). B. Ranera was supported by a doctoral grant from the DGA.

\section{Author details}

${ }^{1}$ Laboratorio de Genética Bioquímica (LAGENBIO), Facultad de Veterinaria, Universidad de Zaragoza, 50013 Zaragoza, Spain. ${ }^{2}$ Hospital Veterinario, Facultad de Veterinaria, Universidad de Zaragoza, 50013 Zaragoza, Spain. ${ }^{3}$ Instituto Aragonés de Ciencias de la Salud (IACS), Zaragoza 50009, Spain.

Received: 3 February 2012 Accepted: 13 August 2012

Published: 22 August 2012

\section{References}

1. Koch TG, Berg LC, Betts DH: Current and future regenerative medicine - principles, concepts, and therapeutic use of stem cell therapy and tissue engineering in equine medicine. Can Vet J 2009, 50(2):155-165.

2. Harrison JS, Rameshwar P, Chang V, Bandari P: Oxygen saturation in the bone marrow of healthy volunteers. Blood 2002, 99(1):394.

3. Pasarica M, Sereda OR, Redman LM, Albarado DC, Hymel DT, Roan LE, Rood JC, Burk DH, Smith SR: Reduced adipose tissue oxygenation in human obesity: evidence for rarefaction, macrophage chemotaxis, and inflammation without an angiogenic response. Diabetes 2009 58(3):718-725

4. Semenza GL: HIF-1, O(2), and the 3 PHDs: how animal cells signal hypoxia to the nucleus. Cell 2001, 107(1):1-3.

5. Ohnishi S, Yasuda T, Kitamura S, Nagaya N: Effect of hypoxia on gene expression of bone marrow-derived mesenchymal stem cells and mononuclear cells. Stem Cells 2007, 25(5):1166-1177.

6. Chacko SM, Ahmed S, Selvendiran K, Kuppusamy ML, Khan M, Kuppusamy $P$ : Hypoxic preconditioning induces the expression of prosurvival and proangiogenic markers in mesenchymal stem cells. Am J Physiol Cell Physiol 2010, 299(6):C1562-C1570.

7. Zhu W, Chen J, Cong X, Hu S, Chen X: Hypoxia and serum deprivation-induced apoptosis in mesenchymal stem cells. Stem Cells 2006, 24(2):416-425.

8. Ren H, Cao Y, Zhao Q, Li J, Zhou C, Liao L, Jia M, Cai H, Han ZC, Yang R, et al: Proliferation and differentiation of bone marrow stromal cells under hypoxic conditions. Biochem Biophys Res Commun 2006, 347(1):12-21.

9. Holzwarth C, Vaegler M, Gieseke F, Pfister SM, Handgretinger R, Kerst G, Muller I: Low physiologic oxygen tensions reduce proliferation and differentiation of human multipotent mesenchymal stromal cells. BMC Cell Biol 2010, 11:11.

10. Lennon DP, Edmison JM, Caplan Al: Cultivation of rat marrow-derived mesenchymal stem cells in reduced oxygen tension: effects on in vitro and in vivo osteochondrogenesis. J Cell Physiol 2001, 187(3):345-355

11. D'Ippolito G, Diabira S, Howard GA, Roos BA, Schiller PC: Low oxygen tension inhibits osteogenic differentiation and enhances stemness of human MIAMI cells. Bone 2006, 39(3):513-522.

12. Godwin EE, Young NJ, Dudhia J, Beamish IC, Smith RK: Implantation of bone marrow-derived mesenchymal stem cells demonstrates improved outcome in horses with overstrain injury of the superficial digital flexor tendon. Equine Vet J 2011, 44:25-32.

13. Frisbie DD, Kisiday JD, Kawcak CE, Werpy NM, Mcllwraith CW: Evaluation of adipose-derived stromal vascular fraction or bone marrow-derived mesenchymal stem cells for treatment of osteoarthritis. J Orthop Res 2009, 27(12):1675-1680.
14. Grimshaw MJ, Mason RM: Bovine articular chondrocyte function in vitro depends upon oxygen tension. Osteoarthr Cartil 2000, 8(5):386-392.

15. Zhao J, Zhang P, Qin L, Pan XH: Hypoxia is essential for bone-tendon junction healing: the molecular biological evidence. Int Orthop 2010, 35(6):925-928

16. Rosova I, Dao M, Capoccia B, Link D, Nolta JA: Hypoxic preconditioning results in increased motility and improved therapeutic potential of human mesenchymal stem cells. Stem Cells 2008, 26(8):2173-2182

17. Berg L, Koch T, Heerkens T, Bessonov K, Thomsen P, Betts D: Chondrogenic potential of mesenchymal stromal cells derived from equine bone marrow and umbilical cord blood. Vet Comp Orthop Traumatol 2009, 22(5):363-370.

18. Schnabel LV, Lynch ME, van der Meulen MC, Yeager AE, Kornatowski MA, Nixon AJ: Mesenchymal stem cells and insulin-like growth factor-I gene-enhanced mesenchymal stem cells improve structural aspects of healing in equine flexor digitorum superficialis tendons. J Orthop Res 2009, 27(10):1392-1398.

19. Carrade DD, Owens SD, Galuppo LD, Vidal MA, Ferraro GL, Librach F, Buerchler S, Friedman MS, Walker NJ, Borjesson DL: Clinicopathologic findings following intra-articular injection of autologous and allogeneic placentally derived equine mesenchymal stem cells in horses. Cytotherapy 2010, 13(4):419-430.

20. Guest DJ, Smith MR, Allen WR: Equine embryonic stem-like cells and mesenchymal stromal cells have different survival rates and migration patterns following their injection into damaged superficial digital flexor tendon. Equine Vet J 2010, 42(7):636-642.

21. Watts $A E$, Yeager AE, Kopyov OV, Nixon AJ: Fetal derived embryonic-like stem cells improve healing in a large animal flexor tendonitis model. Stem Cell Res Ther 2011, 2(1):4.

22. Vidal MA, Kilroy GE, Johnson JR, Lopez MJ, Moore RM, Gimble JM: Cell growth characteristics and differentiation frequency of adherent equine bone marrow-derived mesenchymal stromal cells: adipogenic and osteogenic capacity. Vet Surg 2006, 35(7):601-610.

23. Arnhold SJ, Goletz I, Klein H, Stumpf G, Beluche LA, Rohde C, Addicks K, Litzke LF: Isolation and characterization of bone marrow-derived equine mesenchymal stem cells. Am J Vet Res 2007, 68(10):1095-1105.

24. Mambelli LI, Santos EJ, Frazao PJ, Chaparro MB, Kerkis A, Zoppa AL, Kerkis I: Characterization of equine adipose tissue-derived progenitor cells before and after cryopreservation. Tissue Eng Part C Methods 2009, 15(1):87-94

25. Toupadakis CA, Wong A, Genetos DC, Cheung WK, Borjesson DL, Ferraro GL, Galuppo LD, Leach JK, Owens SD, Yellowley CE: Comparison of the osteogenic potential of equine mesenchymal stem cells from bone marrow, adipose tissue, umbilical cord blood, and umbilical cord tissue. Am J Vet Res 2010, 71(10):1237-1245.

26. Ranera B, Ordovas L, Lyahyai J, Bernal ML, Fernandes F, Remacha AR, Romero A, Vazquez FJ, Osta R, Cons C, et al: Comparative study of equine bone marrow and adipose tissue-derived mesenchymal stromal cells. Equine Vet J 2011, 44(1):33-42.

27. Dos Santos F, Andrade PZ, Boura JS, Abecasis MM, da Silva CL, Cabral JM: Ex vivo expansion of human mesenchymal stem cells: a more effective cell proliferation kinetics and metabolism under hypoxia. J Cell Physiol 2010, 223(1):27-35.

28. Chung DJ, Hayashi K, Toupadakis CA, Wong A, Yellowley CE: Osteogenic proliferation and differentiation of canine bone marrow and adipose tissue derived mesenchymal stromal cells and the influence of hypoxia. Res Vet Sci 2010, 92(1):66-75.

29. Zeng HL, Zhong Q, Qin YL, Bu QQ, Han XA, Jia HT, Liu HW: Hypoxia-mimetic agents inhibit proliferation and alter the morphology of human umbilical cord-derived mesenchymal stem cells. BMC Cell Biol 2011, 12:32.

30. Gardner LB, Li Q, Park MS, Flanagan WM, Semenza GL, Dang CV: Hypoxia inhibits G1/S transition through regulation of p27 expression. J Biol Chem 2001, 276(11):7919-7926

31. lida T, Mine S, Fujimoto $H$, Suzuki K, Minami $Y$, Tanaka $Y$ : Hypoxia-inducible factor-1alpha induces cell cycle arrest of endothelial cells. Genes Cells 2002, 7(2):143-149.

32. Koshiji M, Kageyama Y, Pete EA, Horikawa I, Barrett JC, Huang LE: HIF-1alpha induces cell cycle arrest by functionally counteracting Myc. EMBO J 2004, 23(9):1949-1956. 
33. Peterson KM, Aly A, Lerman A, Lerman LO, Rodriguez-Porcel M: Improved survival of mesenchymal stromal cell after hypoxia preconditioning: role of oxidative stress. Life Sci 2010, 88(1-2):65-73.

34. Volkmer E, Kallukalam BC, Maertz J, Otto S, Drosse I, Polzer H, Bocker W, Stengele M, Docheva D, Mutschler W, et al: Hypoxic preconditioning of human mesenchymal stem cells overcomes hypoxia-induced inhibition of osteogenic differentiation. Tissue Eng Part A 2010, 16(1):153-164.

35. Lavrentieva A, Majore I, Kasper C, Hass R: Effects of hypoxic culture conditions on umbilical cord-derived human mesenchymal stem cells. Cell Commun Signal 2010, 8:18.

36. Nakanishi C, Nagaya N, Ohnishi S, Yamahara K, Takabatake S, Konno T, Hayashi K, Kawashiri MA, Tsubokawa T, Yamagishi M: Gene and protein expression analysis of mesenchymal stem cells derived from rat adipose tissue and bone marrow. Circ J 2011, 75(9):2260-2268.

37. Lee RH, Kim B, Choi I, Kim H, Choi HS, Suh K, Bae YC, Jung JS: Characterization and expression analysis of mesenchymal stem cells from human bone marrow and adipose tissue. Cell Physiol Biochem 2004, 14(4-6):311-324.

38. Pascucci L, Curina G, Mercati F, Marini C, Dall'aglio C, Paternesi B, Ceccarelli $P$ : Flow cytometric characterization of culture expanded multipotent mesenchymal stromal cells (MSCs) from horse adipose tissue: Towards the definition of minimal stemness criteria. Vet Immunol Immunopathol 2011, 144(3-4):499-506.

39. Braun J, Hack A, Weis-Klemm M, Conrad S, Treml S, Kohler K, Walliser U, Skutella T, Aicher WK: Evaluation of the osteogenic and chondrogenic differentiation capacities of equine adipose tissue-derived mesenchymal stem cells. Am J Vet Res 2010, 71(10):1228-1236.

40. Raabe O, Shell K, Wurtz A, Reich CM, Wenisch S, Arnhold S: Further insights into the characterization of equine adipose tissue-derived mesenchymal stem cells. Vet Res Commun 2011, 35(6):355-365.

41. de Mattos Carvalho A, Alves AL, Golim MA, Moroz A, Hussni CA, de Oliveira $P G$, Deffune E: Isolation and immunophenotypic characterization of mesenchymal stem cells derived from equine species adipose tissue. Vet Immunol Immunopathol 2009, 132(2-4):303-306.

42. Radcliffe $\mathrm{CH}$, Flaminio MJ, Fortier LA: Temporal analysis of equine bone marrow aspirate during establishment of putative mesenchymal progenitor cell populations. Stem Cells Dev 2010, 19(2):269-282.

43. Ranera B, Lyahyai J, Romero A, Vazquez FJ, Remacha AR, Bernal ML, Zaragoza P, Rodellar C, Martin-Burriel I: Immunophenotype and gene expression profiles of cell surface markers of mesenchymal stem cells derived from equine bone marrow and adipose tissue. Vet Immunol Immunopathol 2011, 144(1-2):147-154

44. Nekanti U, Dastidar S, Venugopal P, Totey S, Ta M: Increased proliferation and analysis of differential gene expression in human Wharton's jelly-derived mesenchymal stromal cells under hypoxia. Int J Biol Sci 2010, 6(5):499-512.

45. Na KH, Lee HJ, Choi JH, Eun JW, Nam SW, Yoon TK, Kim GJ: Dynamic alterations in integrin alpha4 expression by hypoxia are involved in trophoblast invasion during early implantation. J Cell Biochem 2011, 113(2):685-694.

46. Deguchi JO, Yamazaki H, Aikawa E, Aikawa M: Chronic hypoxia activates the Akt and beta-catenin pathways in human macrophages. Arterioscler Thromb Vasc Biol 2009, 29(10):1664-1670.

47. Violini S, Ramelli P, Pisani LF, Gorni C, Mariani P: Horse bone marrow mesenchymal stem cells express embryo stem cell markers and show the ability for tenogenic differentiation by in vitro exposure to BMP-12. BMC Cell Biol 2009, 10:29.

48. Ezashi T, Das P, Roberts RM: Low $\mathrm{O} 2$ tensions and the prevention of differentiation of hES cells. Proc Natl Acad Sci U S A 2005, 102(13):4783-4788

49. Fehrer C, Brunauer R, Laschober G, Unterluggauer H, Reitinger S, Kloss F, Gully C, Gassner R, Lepperdinger G: Reduced oxygen tension attenuates differentiation capacity of human mesenchymal stem cells and prolongs their lifespan. Aging Cell 2007, 6(6):745-757.
50. Grayson WL, Zhao F, Izadpanah R, Bunnell B, Ma T: Effects of hypoxia on human mesenchymal stem cell expansion and plasticity in $3 \mathrm{D}$ constructs. J Cell Physiol 2006, 207(2):331-339.

51. Mathieu J, Zhang Z, Zhou W, Wang AJ, Heddleston JM, Pinna CM, Hubaud A, Stadler B, Choi M, Bar M, et al: HIF induces human embryonic stem cell markers in cancer cells. Cancer Res 2011, 71(13):4640-4652.

doi:10.1186/1746-6148-8-142

Cite this article as: Ranera et al:: Effect of hypoxia on equine mesenchymal stem cells derived from bone marrow and adipose tissue. BMC Veterinary Research 2012 8:142.

\section{Submit your next manuscript to BioMed Central and take full advantage of:}

- Convenient online submission

- Thorough peer review

- No space constraints or color figure charges

- Immediate publication on acceptance

- Inclusion in PubMed, CAS, Scopus and Google Scholar

- Research which is freely available for redistribution

Submit your manuscript at www.biomedcentral.com/submit
C Biomed Central 